\title{
Comparative Study on Effectiveness of Doxapram and Pethidine for Postanaesthetic Shivering
}

\author{
Shrestha $A B^{1}$ \\ 'Paropakar Maternity and Women's Hospital, Thapathali, Kathmandu, Nepal
}

\section{ABSTRACT}

Introduction: Postanaesthetic shivering is a common condition after surgery which needs proper management with pharmacologic agents so as to make postoperative period comfortable to the patient and prevent from the untoward complications that can arise from it. This study was done to compare the effectiveness of Pethidine and Doxapram in the treatment of postanaesthetic shivering.

Methods: Patients were randomly divided into three groups, ten in each. All received volume of $3 \mathrm{ml}$ as Group I (Doxapram $1.5 \mathrm{mg} / \mathrm{kg}$ ), Group II (Pethidine $0.35 \mathrm{mg} / \mathrm{kg}$ ) and Group III (Normal Saline). All patients were observed for 30 minutes after reversal of muscle relaxant and occurrence of shivering within this period was observed, scored and treated. All treated patients were observed for 10 minutes after the test drug was given for control of shivering and any untoward effects.

Results: Pethidine was found more effective than Doxapram in treating postanaesthetic shivering as it was effective in $80 \%$ followed by Doxapram in $60 \%$ and Normal saline in $20 \%$. Statistically the results between Normal saline and Pethidine was significant as $\mathrm{P}<0.05$. As statistical significance between Doxapram and Normal Saline was $p=0.16$; and between Pethidine and Doxapram was $\mathrm{p}=0.62$, the difference is statistically not significant.

Conclusions: Pethidine was found to be more effective compared to Doxapram in treating patients with postoperative shivering.

Key Words: doxapram, pethidine, postanesthetic shivering

\section{INTRODUCTION}

Postanaesthetic shivering is a very common complication of general anaesthesia with a reported incidence varying from $5-65 \% .^{1,2}$ Patients report that shivering is remarkably uncomfortable, and some even find it worse than surgical pain. ${ }^{1}$ It is important to prevent or treat postanaesthetic shivering because of distress it causes to the patient and the consequences of which may sometimes be fatal.

Differentmethods have been used to treatpostanaesthetic shivering till date. There are pharmacological and non pharmacological measures. Pharmacological measures includes agents like: doxapram, pethidine, amino acids, clonidine, metamizole, tramadol, nefopam, nalbuphine,

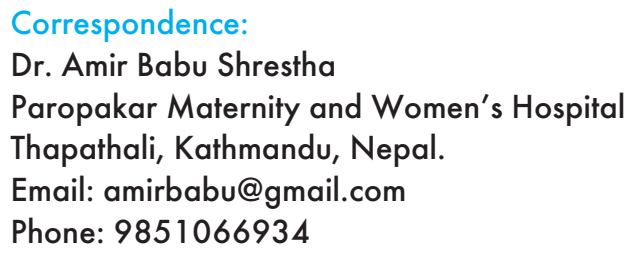


physostigmine, ondansetron, fentanyl, alfentanyl, sufentanyl, and urapidil.2-16 Non pharmacological measures like use of space blankets have also shown to decrease the incidence of postanaesthetic shivering. ${ }^{17}$

Among many pharmacological agents, Pethidine and Doxapram have been found to be very effective in the control of postanaesthetic shivering. In this study, the effectiveness of Pethidine and Doxapram and placebo (normal saline) for control of post anaesthetic shivering in 30 patients (10 patients in each group) was compared.

\section{METHODS}

A prospective double blind study was conducted in Bir Hospital among patients who underwent surgery under general anesthesia and who developed shivering. Total of 30 patients with ASA (American Society of Anesthesiologists) physical status I and II who underwent general and orthopaedic surgeries were included in the study after obtaining institutional approval and written informed consent. Following patients were excluded:

1. Patients not meeting the criteria for ASA I And II

2. Patients with history of seizures

3. Hypertensive patients and

4. Patients with known hypersensitivity to pethidine or doxapram.

Patients were randomly divided into three groups, 10 in each. Randomization, allocation of drugs and placebo among the study patients were done by the anaesthetic nurse, keeping the principal researcher unaware of the drug and placebo assignment. Group I received $1.5 \mathrm{mg} /$ $\mathrm{kg}$ body wt. of Doxapram, Group II received $0.35 \mathrm{mg} /$ $\mathrm{kg}$ body wt. of Pethidine and Group III received normal saline in equal volume of $3 \mathrm{ml}$ injectable solutions. All patients who underwent surgery were premedicated with diazepam $5 \mathrm{mg}$ (in patients $<50 \mathrm{~kg}$ body wt) and $10 \mathrm{mg}$ (in patients $>50 \mathrm{~kg}$ body wt.) orally at night.

After receiving the patient in operation theatre an intravenous line was secured, and continuous monitoring (ECG, pulseoximetry, NIBP, thermometer) was started. Anaesthesia was induced with Sodium thiopentone $5 \mathrm{mg} / \mathrm{kg}$, Pethidine $(0.5 \mathrm{mg} / \mathrm{kg})$ was given for analgesia and Succinylcholine $1.5 \mathrm{mg} / \mathrm{kg}$ was given to facilitate intubation. Anaesthesia was maintained with Halothane, Pancuronium and Pethidine as and when needed. After completion of surgery, effects of muscle relaxants was reversed with Neostigmine $0.05 \mathrm{mg} / \mathrm{kg}$ and atropine $0.02 \mathrm{mg} / \mathrm{kg}$ and extubated after adequacy of ventilation was confirmed.

Operation theatre temperature was maintained at $18^{\circ} \mathrm{C}$. Temperature of IV fluids was warmed up to $18^{\circ} \mathrm{C}$. Patients were observed by investigator for 30 minutes inside the operating room after reversal of anaesthesia and occurrence of shivering within this period was observed, scored and treated.

The investigator who gave the injection was unaware of the nature of the drug received by the unaware patient from identical syringes containing either Normal saline, Doxapram or Pethidine with equal volume prepared by anaesthetic nurse.

Shivering grade scoring was done according to the shivering grade given in the table (Table1). Grading was done before the test drug was given and then at every subsequent two minutes after treatment for 10 minutes with other monitored data in specially formulated data collection form. Level of monitoring at recovery room was also the same as in operation theatre.

\section{Table 1. Grading of Shivering}

\begin{tabular}{cl}
\hline Grade & \multicolumn{1}{c}{ Shivering } \\
\hline 0 & $\begin{array}{l}\text { No shivering } \\
\text { One or more of : piloerection, peripheral } \\
\text { vasoconstriction, peripheral cyanosis } \\
\text { without other causes, but without visible } \\
\text { muscular activity }\end{array}$ \\
2 & $\begin{array}{l}\text { Visible muscular activity confined to one } \\
\text { muscle group }\end{array}$ \\
3 & $\begin{array}{l}\text { Visible muscular activity in more than one } \\
\text { muscle group } \\
4\end{array}$ \\
Gross muscular activity involving entire \\
body.
\end{tabular}

Statistical analysis of data collection was done by using ANOVA test (analysis of variance test) for comparison of means between the different groups with regard to age, weight, duration of anaesthesia, heart rate and systolic and diastolic arterial blood pressure and peripheral body temperature.

\section{RESULTS}

Among thirty studied patients, ten in each group: in group I, six out of ten who received Doxapram stopped and four continued shivering. In group II, eight patients stopped shivering who received Pethidine and in group III only two who received normal saline stopped shivering and eight continued. So the effectiveness of Pethidine was found significantly higher as compared to normal saline.

Statistically the results between Normal saline and Pethidine was found significant as $P<0.05$. As statistical significance between Doxapram and Normal Saline was $\mathrm{P}>0.05$; and between Pethidine and Doxapram was $P>0.05$, the difference is statistically not significant.

The mean time taken for development of shivering after stoppage of anaesthesia was 12.70 in group I, 8.90 
Shrestha et al. Comparative study on effectiveness of Doxapram and Pethidine for Postanaesthetic shivering

minutes in group II and 15 minutes in group III, ranging from 5 to 30 minutes, 0 to 25 minutes and 5 to 35 minutes respectively. Thus there was no significant difference $\mathrm{P}>0.05$ between group I and II, Group II and III and III and I.

The mean time of general anaesthesia taken for surgery in group I was 72 minutes, in group II 111.30 minutes and in group III 91 minutes. So statistically there were no significant $\mathrm{P}>0.05$ between group I and II and group II and III and group III and I.

The mean time difference between development of shivering and research medicine given in group I was 5.70 minutes, in group II 3.10 and in group III 3.50 minutes. Thus there were no significance between three groups as their $\mathrm{P}>0.05$ in each case.

Among those who stopped shivering the mean time taken to stop shivering after research medicine given was 6.33 minutes in group I, in group II the time was 6.75 minutes and in group III 6.00 minutes. Thus there was no significance in time difference between the research medicine given and shivering stopped in group I and II, group II and III and group III and I as their $\mathrm{p}=$ $0.78,0.72$ and 0.91 respectively.

Of the 30 patients involved, age in Group I varied from 20-65 years (mean 35.1 years); in Group II , 19-57 years (mean 35.4 years) and in Group III, 21-54 years (mean 32.4 years).

Of the total 30 patients, 8 were female $(26.7 \%)$ and 22 were male $(73.3 \%)$.

In Group I, weight varied from 45-70kg (mean $56.6 \mathrm{~kg}$ ); in Group II, 40-61 kg (mean 52.4kg) and in Group III 42$62 \mathrm{~kg}$ (mean $55.2 \mathrm{~kg}$ ).

The types of surgery carried out were as follows: Cholecystectomy $(n=14)$, Pyelolithotomy $(n=8)$, Breast carcinoma excision $(n=2)$, Appendicectomy $(n=2)$, Open reduction and immobilization $(n=2)$, Common bile duct exploration $(n=1)$ and Haemangioma excision $(n=1)$.

The duration of general anaesthesia taken for surgery in Group I ranged from 35-135 minutes (mean 72 minutes); in Group II ranged from 75-165 minutes (mean 111.3 minutes) and in Group III ranged from 55-155 minutes (mean 91 minutes).

The time taken to develop shivering after anaesthesia stopped was 5-30 minutes (mean 12.7 minutes) in Group I; 0-25 minutes (mean 8.9 minutes) in Group II and 5-35 minutes (mean 15 minutes) in Group III.
Table 2. Time taken to develop shivering after anaesthesia stopped (minutes)

\begin{tabular}{lccc}
\hline & Gr. I & Gr. II & Gr. III \\
\hline Number & 10 & 10 & 10 \\
Minimum & 5 & 0 & 5 \\
Maximum & 30 & 25 & 35 \\
Mean & 12.70 & 8.90 & 15.00 \\
SD & 8.45 & 7.65 & 9.24 \\
\hline
\end{tabular}

Table 3. Differences of time between shivering started and research drug given (minutes)

\begin{tabular}{llll}
\hline & Gr. I & Gr. II & Gr. III \\
\hline Number & 10 & 10 & 10 \\
Minimum & 2 & 1 & 0 \\
Maximum & 10 & 6 & 5 \\
Mean & 5.70 & 3.10 & 3.50 \\
SD & 4.30 & 1.97 & 1.90 \\
\hline
\end{tabular}

Table 4. Differences of time between research drug given and control of shivering (minutes)

\begin{tabular}{llll}
\hline & Gr. I & Gr. II & Gr. III \\
\hline Number & 6 & 8 & 2 \\
Minimum & 1 & 4 & 3 \\
Maximum & 10 & 10 & 9 \\
Mean & 6.33 & 6.75 & 6.00 \\
SD & 3.39 & 2.38 & 4.24 \\
\hline
\end{tabular}

Among thirty patients, 6 out of 10 stopped shivering in group I. In Group II, 8 out of 10 stopped shivering and in Group III, only 2 out of 10 stopped shivering. So the effectiveness of Pethidine was found significantly higher as compared to normal saline (Table 5).

The results between Normal saline and Pethidine was found significant $(P<0.05)$. However, the results between Doxapram and Normal saline $\mathrm{P}>0.05$; and between Pethidine and Doxapram ( $P>0.05)$ were not significant statistically.

Table 5. Outcome of Shivering

\begin{tabular}{llll}
\hline & Group I & Group II & Group III \\
\hline $\begin{array}{l}\text { Shivering } \\
\text { Stopped }\end{array}$ & $6(60 \%)$ & $8(80 \%)$ & $2(20 \%)$ \\
$\begin{array}{l}\text { Shivering } \\
\text { continued }\end{array}$ & $4(40 \%)$ & $2(20 \%)$ & $8(80 \%)$ \\
Total & $10(100 \%)$ & $10(100 \%)$ & $10(100 \%)$ \\
\hline
\end{tabular}

\section{DISCUSSION}

Postanaesthetic shivering is a very common complication of general anaesthesia with a reported incidence 
varying from 5 to $65 \%$. Patients report that shivering is remarkably uncomfortable and some even find it worse than surgical pain. ${ }^{2}$

This study showed that both Pethidine and Doxapram were effective in controlling postanaesthetic shivering but there was no statistically significant between the two. However, Pethidine was found more effective as the shivering was controlled in 8 patients compared to 6 in case of Doxapram. Many studies done so far also document Pethidine more effective and superior to Doxapram for the control of postanaesthetic shivering. In a study of group of patients who developed postanaesthetic shivering after receiving inhalational anaesthesia found a significantly higher proportion of patients stopped shivering after being given Doxapram than after placebo. ${ }^{2}$ Similarly one study which compared the effectiveness of Doxapram and Pethidine in the treatment of post-anaesthetic shivering with saline as placebo found that Doxapram and Pethidine were both effective in controlling shivering. In Doxapram group, $85 \%(n=17)$ of patients stopped shivering within 10 minutes whereas in Pethidine group $100 \% \quad(n=20)$ of patients stopped shivering with only $25 \%(n=5)$ in control group. ${ }^{1}$ In another study done in 220 healthy patients who shivered following routine surgery on the minimum effective doses of Pethidine and Doxapram in the treatment of post-anaesthetic shivering and concluded that $0.35 \mathrm{mg} / \mathrm{kg}$ of Pethidine is the minimum dose required to treat postanaesthetic shivering effectively. They also concluded that $0.18 \mathrm{mg} / \mathrm{kg}$ of Doxapram is as effective as $1.4 \mathrm{mg} / \mathrm{kg}$ in the treatment of postanaesthetic shivering. ${ }^{18}$

Shivering is one of the mechanisms to increase body temperature which is mediated by the primary motor center in the hypothalamus in response to the cold signals from the skin and spinal cord. ${ }^{19}$ The integrity and effectiveness of the thermoregulatory system is adversely affected by several factors including age, disease, injury, and various pharmacologic agents. Specifically anaesthetics have been shown to inhibit thermoregulatory control in animals and humans. As a result, anaesthetized patients often become hypothermic during surgery. Perioperative hypothermia may predispose to complications including postoperative shivering, impaired coagulation, decreased cutaneous blood flow, slowed drug metabolism, and decreased resistance to surgical wound infection. ${ }^{20}$ Exact mechanism of how Pethidine controls postanaesthetic shivering is not well documented. Recently it has been found that its antishivering properties are related to its binding with kappa receptors and specific actions on temperature regulation centers in the hypothalamus. In one study, the antishivering activity of Pethidine was minimally impaired by low-dose Naloxone (blocking most mu-receptors), but largely prevented by high-dose Naloxone (blocking all mu and most kappa receptors) ${ }^{21}$ thus attributing kappa receptors as the site of action of Pethidine for the control of shivering. It has some spasmogenic effect on certain smooth muscles as well.

Besides pharmacological methods, non pharmacological methods like space blanket have been used which also decreases the incidence of postanaesthetic shivering.

\section{CONCLUSIONS}

Even though there are many pharmacological and non pharmacological methods, Pethidine is one of the best pharmacological agents for the control of postanaesthetic shivering and has been found superior to Doxapram in this study.

\section{REFERENCES}

1. Singh P, Dimitriou V, Mahajan RP, Crossley AWA. Double blind comparision between doxapram and pethidine in the treatment of postoperative shivering. $\mathrm{Br} \mathrm{J}$ Anaesth. 1993;71:635-8.

2. Sarma V, Fry EN. Doxapram after general anaesthesia. Its role in stopping shivering during recovery. Anaesthesiol. 1991;46(6):460-1.

3. Alfred Goodman Gillman and Louis S Goodman. The 7th ed. pharmacological basis of therapeutics. 1985. Chapter 24 .

4. Wrench IJ, Cavill G, Ward J E, Crossley AWA. Comparison between alfentanil, pethidine and placebo in the treatment of post-anaesthetic shivering. Br J Anaesth. 1997;79(4):541-2.

5. Sellden E, Branstrom R, Brundin T. Preoprative infusion of amino acids prevents postoperative hypothermia. Br J Anaesth. 1996;76:227-34.
6. Buggy D, Higgins P, Moran C, O'Donovan F, McCarroll $\mathrm{M}$. Clonidine at induction reduces shivering after general anesthesia. Can J Anaesth. 1997;44(3):263-7.

7. Monso A, Riudeubas J, Barbal F, Laporte J R , Arnau J M. A randomized double blind, placebo controlled trial comparing pethidine to metamizol for treatment of post-anaesthetic shivering. Br J Clin Pharmacol. 1996;42(3):307-11.

8. de Witte J, Deloof T, de Veylder J, Housemans PR. Tramadol in the treatment of postanaesthetic shivering. Acta Anasthesiol Scand. 1997;41(4):506-10.

9. Piper SN, Schmidt CC, Suttner SW, Kumle B, Triem JG, Maleck $\mathrm{WH}$, et al. Prophylactic nefopam administration for postanesthetic shivering. Anasthesiol Intensivmed Notfallmed Schmerzther. 1998 Dec;33(12):786-9. [Article in German]

10. Wang JJ, Ho ST, Lee SC, Liu LC. A comparoson among 
Nalbuphine, meperidine and placebo for treating postanesthetic shivering. Anesth Analg. 88: 686-9.

11. Horn EP, Standl T, Sessler D, Daniel I, Knobelsdorf Gv, Buchs $\mathrm{C}$, et al. Physostigmine prevents postanaesthetic shivering as does Meperidine or clonidine. Anesthesiology. 1998;88:108-13.

12. Powell RM, Buggy DJ. Ondasetron given before induction of anaesthesia reduces shivering after general anaesthesia. Anaesthe and Analg 2001 Jun;90(6):1423-7.

13. Alfonsi P, Hongnat JM, Lebrault C, Chauvin M. The effects of pethidine, fentanil and lignocaine on postanaesthetic shivering. Anaesthesia. 1995 Mar;50(3):214-7.

14. Wrench IJ, Cavill G, Ward JEH, Crossley AWA. Comparison between alfentanil, pethidine, and placebo in the treatment of post-anaesthetic shivering. Br J Anaesth. 1997;79:541-2.

15. Alfonsi P, Sessler DI, Du Manoir B, Levron JC, Le MJP, Chauvan M. The effects of meperidine and sufentanil on the shivering threshold in postoperative patients. Anesthesiology. 1998 Jul;89(1):43-8.
16. Powell RM, Buggy DJ. Influence of ondansetron at induction on thermoregulation and shivering after general anaesthesia. Br J Anaesth. 1999;83:173-4.

17. Buggy D, Hughes N. Preemptive use of the space blanket reduces shivering after general anaesthesia. Br J Anaesth. 1994;72:393-6.

18. Wrench IJ, Singh P, Dennis AR, Mahajan RP, Crossley AW. The minimum effective dose of pethidine and doxapram in the treatment of postanaesthetic shivering. Anaesthsiol. 1997;52(1):32-6.

19. Guyton AC, Hall JE. Textbook of Medical Physiology. 9th ed. WB Saunders; 1998. p.917-8.

20. Giesbrecht GG. Human thermoregulatory inhibition by regional anaesthesia. Anaesthesiol. 1994;81:277-81.

21. Baxendale BR, Mahajan RP, Crossley AWA. Anticholinergic premedication influences the incidence of postoperative shivering. Br J Anaesth. 1994;72:291-4. 